\title{
Erratum to: Monitoring of heavy metals uptake and allocation in Pinus sylvestris organs in alkalised soil
}

\author{
Malle Mandre $\cdot$ Katri Ots
}

Published online: 25 September 2012

(C) Springer Science+Business Media B.V. 2012

Erratum to: Environ Monit Assess, (2012) 184, pp. 4105-4117, DOI 10.1007/s10661-011-2247-8

In the original publication of this article, there was a mistake in the order of authors. The correct order of author names is presented here.

The online version of the original article can be found at http://dx.doi.org/10.1007/s10661-011-2247-8.

M. Mandre $\cdot$ K. Ots $(\bowtie)$

Department of Ecophysiology, Institute of Forestry and

Rural Engineering, Estonian University of Life Sciences,

Viljandi mnt 18B,

11216 Tallinn, Estonia

e-mail: katri.ots@emu.ee 